\title{
Biological Characteristics and Control of Orobanche Crenata Forsk., a Review
}

\author{
Alessia Restuccia, Mario Marchese, Giovanni Mauromicale, Giuseppe Restuccia* \\ Dipartimento di Scienze Agronomiche, Agrochimiche e delle Produzioni Animali \\ (DACPA), Università di Catania \\ Via Valdisavoia 5, 95123 Catania, Italy
}

Received: 31 October 2008. Accepted: 30 March 2009.

\begin{abstract}
Orobanche crenata is a holoparasitic phanerogam which is particularly noxious to legumes, such as faba bean (Vicia faba L.), pea (Pisum sativum L.), chickpea (Cicer arietinum L.), lentil (Lens culinaris Medik.), etc., and commonly considered one of the major causes which has contributed to re-rizing the area designed to their cultivation. After a few brief references on the origin and diffusion of $O$. crenata, in this work summarises the results of research into biological aspects and control of this species. The information obtained especially concerns seed production, seed viability, seed longevity and dormancy, seed conditioning and germination, parasitism phases, the effects of parasite attacks on host plants and the means of control.
\end{abstract}

Key-words: seed production, seed characteristics, parasitism, damage, means of control, crenate broomrape.

\section{Introduction}

The genus Orobanche, from the Greek opoßos and $\alpha \gamma \chi \omega$, according to Fiori (1969), includes 120 species, $90 \%$ of which are indigenous to the warm temperate regions of the Northern hemisphere where, through commerce in seeds, some spread to South America and Oceania (Marudarjan, 1950; Sauerborn, 1991a; Mitich, 1993; Carter et al., 1996; Diaz and Norambuena, 2001; Rubiales et al., 2003a).

These species represent dreadful parasites to numerous crops, such as hemp (Cannabis sativa L.), carrot (Daucus carota L.), cabbage (Brassica oleracea (L.) Alef. conv. capitata L.), chickpea (Cicer arietinum L.), faba bean (Vicia faba L.), sunflower (Helianthus annuus L.), lentil (Lens culinaris Medik.), aubergine (Solanum melongena L.), lucerne (Medicago sativa L.), potato (Solanum tuberosum L.), pea (Pisum sativum L.), celery (Apium graveolens L.), tobacco (Nicotiana tabacum L.), vetch (Vicia sati$v a$ L.), etc. It has been estimated that in the
Mediterranean region, Eastern Europe and Western Asia about 16 million hectares of agricultural land have been infested by Orobanche spp. (Sauerborn, 1991b).

\section{Origin, diffusion and parasitized species}

Listed among the most deleterious species, $O$. crenata Forsk., also known as O. speciosa D.C. in Lam \& D.C. and O. pelargonii Caldesi by Greuter et al. (1989), is considered indigenous in the Mediterranean Basin (Cubero, 1983), but it can be found in many other central northern European countries like Estonia, the Czech Republic, the Netherlands, Northern France, Southern England, Switzerland, Austria and Northern and Central Germany (Kreutz, 1995).

According to Grenz and Sauerborn (2007), the establishment of this species is only possible in areas where a warm dry period is followed by warm wet conditions, and the presence of conditioned seed coincides with that of the host plant. These conditions predominate wher-

\footnotetext{
* Corresponding Author: Tel.: +39 095 234461; Fax: +39 095 234449. E-mail address: g.restuccia@unict.it
} 
ever there is a Mediterranean climate and in parts of the monsoon regions, savannah and dry winter areas of central America, Africa, Australia and Southern Asia. By contrast, its establishment is impossible in humid areas, both temperate and tropical, where the preponderance of dormancy-inducing wet conditions and lack of a warm-dry period which, facilitating dormancy release, prevents seed germination and thus establishment of the species.

Commonly called crenate broomrape, legume burn, flame grass, wolf grass, bull grass, scallion grass, wolf bean, O. crenata is a holoparasite devoid of chlorophyll and totally dependent on the host for organic carbon, water and nitrogen (Joel et al., 2007) and is particularly noxious to legumes (faba bean, pea, chickpea, lentil), being one of the major causes of the decline in their cultivation. Carrot (Daucus carota L.), safflower (Carthamus tinctorious L.), geranium (Geranium spp.), lettuce (Lactuca sativa L.) and many other species, either cultivated or wild, are also parasitized. To explain $O$. crenata's relevance, it had by the beginning of the 1990s, already infested $63 \%$ of the faba bean crop in Morocco, Portugal, Spain and Syria (Sauerborn, 1991b) and this percentage would have been even higher if it had included all those areas abandoned due to over-infestation (Parker e Riches, 1993).

\section{Plant Characteristics and Seed Production}

O. crenata reproduces by seeds; its underground fraction being essentially made of the tubercle and pseudo roots, while above-ground it consists of a floral stem, also called flowering shoot, fleshy, erect, non-branching, 30-70 cm high, sparsely hairy, usually yellowish.

The inflorescence, usually, has numerous flowers in a spike, dense above, often lax below, hairy; the corolla is usually $20-30 \mathrm{~mm}$ long, subglabrous, white; four stamens are inserted 2-3 $\mathrm{mm}$ above the base of the corolla (Tutin et al., 1981). Cross-pollination, normally entomophilous (Cubero, 1983), determines genetic variability (Verkleij et al., 1986; Cubero, 1991; Román et al., 2002) which contributes to explains why $O$. crenata is able to parasite on an increasingly greater number of species. Its fruit is a unilocular capsule $10-12 \mathrm{~mm}$ long (Tutin et al., 1981), which, when ripe, opens into two valves, and above all in early attacks, liberates a large number of very small brown seeds from $1-5 \times 10^{5}$ per spike (Cubero, 1983; Linke and Saxena, 1991; López-Granados and García-Torres, 1991). Seed weights ranging from 3 to $7 \mu \mathrm{g}$ (Linke, 1987; Parker and Riches, 1993), are oval, convex on one side and flat on the other with corresponding micropyle.

The seed has an undifferentiated embryo made of a group of cells surrounded by others rich in reserve substances (endosperm); externally it is covered in a tough seedcoat with an alveolar surface. The alveoli more or less form a pentagon 55-75 x 35-55 $\mu \mathrm{m}$ (Abu Sbaih and Jury, 1994).

\section{Seed viability}

Seeds may be viable (germinable or dormant) or non-viable. The former come mostly from the capsules of the lower and middle third of the spikes, while the latter mostly from the upper third and often, because of an underdeveloped endosperm, are particularly small (Linke and Saxena, 1991).

The results of in-vitro research (Khalaf, 1991) lead one to presume that seed viability is also influenced by area of origin.

The seeds are relatively long-lived (Kardy and Tewfik, 1956; Cubero and Moreno, 1979) which also depends on the environment and conservation conditions. Seed viability proved longer in the laboratory than in the soil where no variations due to depth were observed (Lòpez-Granados and Garcìa-Torres, 1999) or any due to heat/humidity variations (Kebreab and Murdoch, 1999). Referring to this latter, Linke and Saxena (1991) demonstrated that half life was reached after 9 years of storage at low relative humidity, and temperatures not exceeding $25^{\circ} \mathrm{C}$; after 15 years, at the same storage conditions, all seeds had lost viability. The same parameters were reached after 2.5 and 5 years, respectively, when stored at high relative air humidity and temperatures often over $30^{\circ} \mathrm{C}$ during the hot season.

\section{Seed dormancy}

Viable seeds are subject to dormancy (AbuShakra et al., 1970; Edwards, 1972; El-Basyouni, 
1979; Khalaf, 1991; Van Hezewijk et al., 1993; Salisbury and Ross, 1996). Dormancy, which affects about $50 \%$ of viable seeds (Lòpez-Granados and Garcìa-Torres, 1993), may be caused by different factors as yet insufficiently studied.

Among those most commonly cited, they point to the metabolic state of the seed, low endogenous gibberelline or high germination inhibitors in the seed, seed-coat characteristics, the absence of host plant stimulus and long seed exposure to humidity and temperatures unfavourable for germination (Khalaf, 1991; Van Hezewijk et al., 1993; Van Hezewijk et al., 1994; Matusova et al., 2005).

It has been observed that dormancy due to phenolic compounds in the seed disappears after washing in soil water or immersion in water for 2-4 weeks at $20^{\circ} \mathrm{C}$ (Edwards, 1972; Edwards et al., 1976; El Basyouni, 1979).

The dormancy/non-dormancy cycle is typical of an annual weed with autumn germination.

\section{Seedbank}

The copious production of enduring long-life seeds capable of long dormancy accounts for its peculiar seedbank characteristics. It can reach very high values (approximately 4 million seeds $\mathrm{m}^{-2}$ in the $20 \mathrm{~cm}$ depth arable layer) most of which are viable (Lopéz Granados and García Torres, 1993). O. crenata seeds, also extracted from the soil, can be identified by DNA fingerprinting (Portnoy et al., 1997).

\section{Seed conditioning}

The seed must be conditioned, for example by exposure to a moist environment at about $18^{\circ} \mathrm{C}$ for 11 days, in order to be stimulated by the host plant to germinate (Kasasian, 1973). Nevertheless, it has been ascertained that should the length of conditioning exceed the necessary time to ensure the highest percentage of germination, then the seed returns to dormancy. In research by Van Hezewijk et al. (1993) this phenomenon has been confirmed after prolonged exposure at $10-15{ }^{\circ} \mathrm{C}$ and less so at $20{ }^{\circ} \mathrm{C}$.

Seed conditioning is a complex process involving metabolic events as well as those indispensable for germination (Joel et al. 1991) and due to which there is a drastic increase in respiration and the production of hormones and proteins for DNA (Bar-Nun and Mayer, 1993; Joel et al., 1991; Joel et al., 1995a; Joel, 2000).

Increased respiration, which for O. aegyptiaca seed reaches a peak 3 days after conditioning (Bar-Nun and Mayer, 1993), shows that seed preparation for germination involves very active changes. Once past the peak, the seed goes into stand-by, but maintains its receptivity to the stimulus for a relatively long period. The oxygen absorption peak is significantly higher if during conditioning oxygenised gibberellin is applied (Bar-Nun and Mayer, 1993), which also reduces the minimum useful exposure time to the stimulant (Joel et al., 1991; Joel et al., 2000) and promotes germination (Nash and Wilhelm, 1960; Hsiao et al., 1988).

Conditioned seeds respond to very low concentrations $\left(10^{-7}-10^{-15} \mathrm{M}\right)$ of germination stimulants, such as strigolactones, which are normally released from host roots (Wigchert and Zwanenburg, 1999). Stimulant concentrations which are higher than optimal, inhibit seed germination (Joel et al., 1995a; Joel, 2000).

\section{Seed germination}

Seed germination is barely influenced by the increase in soil pH from 5 to 8.5 (Van Hezewijk et al., 1994) and by the lowering of the osmotic potential from 0 to $-0.5 \mathrm{MPa}$. This latter parameter, on the contrary, shortens germ tube length. (Nandula, 1998).

Acid scarification with dilute concentrations of $\mathrm{H}_{2} \mathrm{SO}_{4}(0.5 \mathrm{~N})$ for short periods of time (from 1 to $20 \mathrm{~min}$ ) or prechilling treatments at temperatures of around $0{ }^{\circ} \mathrm{C}$ from $24 \mathrm{~h}$ to $6 \mathrm{~d}$ increased seed germination (Lòpez-Granados and Garcìa-Torres, 1996).

Lag time strongly increased with decreasing temperatures and at $5{ }^{\circ} \mathrm{C}$ it was 20 days. Germination percentage was maximal within a narrow temperature range, from approximately 15 to $20{ }^{\circ} \mathrm{C}$; at 0 and $35{ }^{\circ} \mathrm{C}$ no germination took place (Kasasian, 1973; Van Hezewijk et al., 1991).

The identification of the stimulants exuded by host roots was not easy also because of their low concentration and probable transformation by soil micro-organisms (Steinkellner et al., 
2007). It is widely held, however, that they can be active or precursors to conversion into germination inducers.

In the root excretions of the faba bean at least 8 gibberellines capable of stimulating germination have been found (El-Ghamrawy et al., 1990; El-Ghamrawy and Neumann, 1991), but none includes gibberellic acid $\left(\mathrm{GA}_{3}\right)$. Since the latter cannot induce germination alone, while if added to stimulants it increases noticeably (Hassan et al., 1980), it has been suggested that its presence in the seed is to perceive the stimulant (El-Ghamrawy et al., 1990; El-Ghamrawy and Neumann, 1991). This is different in relation to the host plant (Restuccia and Mauromicale, 1991); in faba bean the stimulus reaches the maximum effectiveness nearing the phase change from vegetative to reproductive, more precisely a week before and about five days after the start of flowering in the autumn/spring crop and in the spring/summer crop (El-Ghamrawy and Neumam, 1991). This data on the autumn/spring cycle of the cultivated faba bean would seem to confirm the results of Restuccia and Mauromicale (1991), who verified that the highest percentages of germination are assured by the root extracts from the main shoot of plants at the development stage of the $8^{\mathrm{t}}-10^{\text {th }}$ leaf.

Very little is known about the mechanism behind receiving the stimulus and initiating germination, even if it has been hypothesised that initiation is made possible by physiological changes taking place within the seed itself such as the transformation of inhibitors and/or the increase in stimulators (Evenari, 1949; Mayer and Shain, 1974).

\section{Parasitism phases}

Germination begins with the enlarging of the micropyle zone of the seed, which is followed by the emergence of the germ tube, a yellowywhite tubular organ, whose apex formed of active meristematic cells, seems slightly swollen. Once past the seedcoat, the germ tube elongates by division and cellular distension (Parker and Riches, 1993), and most probably guided by a chemiotrophic gradient, in the 2-3 days after the start of germination, makes contact with the host plant root.
Since this contact must be made before the endosperm reserve runs out, even at risk of seed death, it is only believed possible if the seedroot distance amounts to a few millimeters in length (Kardy and Tewfic, 1956; Ter-Borg, 1986). Frequently, contact is with secondary host roots (Aber, 1984), above all in the area of prolongation and active absorption (Foy et al., 1989) or in relation to root nodules (Kukula and Masri, 1985). This latter observation holds that there is a relationship between $O$. crenata and Rhizobium (Musselman, 1980; Morozov et al., 2000; Mabrouk et al. 2007). It should be noted, however, that in the pea, an inoculum with compatible Rhizobium strains (P.SOM and P. 1236) can protect the pea against $O$. crenata attack by reducing active host root exudation and by preventing parasite attachment and growth of installed tubercles. As the attacks decrease, peroxidase and phenylalanine ammonia lyase activity increases in the pea roots (Mabrouk et al., 2007).

In research by López Granados and García Torres (1993), about $3 \times 10^{-3 \%}$ of the seedbank became attached to the root and of these only $9 \%$ developed and emerged from the soil, probably reflecting high levels of intraspecific competition.

Once contact with the host root is made, the germ tube immediately forms an appressorium, followed by haustoria production. The germ tube stops extending itself, the apex expands and the peripheral cells become papillars. On the outer surface of these cells, protuberances begin to form covered by a cuticle which secretes a carbohydrate. Once accumulated it then discharges to create a thin adhesive layer which glues the parasite to the host (Baird and Riopel, 1985; Joel and Losner-Goshen, 1994).

The independent life phase, facilitated by the consumption of material stored in the seed, lasts a few days until the parasite finds a host, and attaches to it. The next parasitic life phase starts as soon as the intrusive cells of the haustorium (specialized transfer structure) make a physiological bridge with the host. At this point the parasite becomes dependent on nutrients from the host (Joel, 2000).

The penetration of the haustorium into the root tissue is facilitated by both the mechanical force generated by its growth (Dörr and Kollman, 1974) and its enzymatic activities which 
change wall composition in the host tissues, thereby facilitating the separation of neighboring host cells (Joel and Losner-Goshen, 1994). The enzymes involved are thought to be polygalacturonase, carbomethylcellulase, ß-glycosidase (whose activity peaks 2-3 days after germination by which time the parasite must have attached itself to the host) and pectin methyl esterase (PME) (Aber and Sallé, 1983; LosnerGoshen et al., 1998). Furthermore, it is presumed that in the endodermis, whose cells are impregnated with cutin and suberin, haustorium penetration is facilitated by cutinase (Joel et al., 1998; Joel, 2000).

There is a direct connection between the haustorium and the host's xylem (Saghir et al., 1973; Dörr and Kollman, 1976; Pennypacker et al., 1979; Visser and Dörr, 1987), whereas for the phloem they have not as yet been clearly identified and seem to indirectly involve contact (Dörr and Kollman, 1975) or polymorphic cells (Pennypacker et al., 1979; Rajanna et al., 2005), on several occasions observed in direct contact with host sieve cells. Dörr and Kollman (1995) also noticed interspecific sieve pores derived from plasmodesmata at the points where both the host cells and those of the parasite differentiate into sieve elements (Nandula, 1998). Once the connection is established, the parasite development is fully coordinated by the host. Their synchronised life leads to the formation of continuous vessels which act like a bridge between the two (Joel, 2000).

Once the cauline cells of the parasite on the outside of the root take in organic ions, metabolites, hormones and water from the host, they begin to multiply rapidly, so a tubercle starts to form. It is an organ of nutritive accumulation whose external surface produces numerous conical protuberances from which pseudo roots grow. In research by Restuccia et al. (2005), the $S_{1}$ phase (Ter Borg et al., 1994) of the first tubercles were observed after 41 days (fully expanded $7^{\text {th }}$ and $8^{\text {th }}$ leaf on the main shoot) and 77 days (fully expanded $11^{\text {th }}$ and $12^{\text {th }}$ leaf on the main shoot) from the emergence of the host plant both in Vicia faba major and in V. faba minor cultivated in the autumn/spring cycle and respectively sown in the first ten days of November or about a month later. Similar results after sowing at the same time in November were obtained by Perez-de Luque et al. (2005a) for Pisum sativum and P. fulvum accessions grown in a controlled environment.

Normally 1-2 weeks after formation of the tubercle, a bud appears in the upper part encircled by scale leaves which give rise to the flowering shoot.

\section{Emergence of the flowering shoot, seed ripening and dissemination}

Generally, the flowering shoot emerges from the ground during the flowering-setting of the host plant (Van Hezewijk et al., 1993) and initially, above all if the air temperature is around $30{ }^{\circ} \mathrm{C}$, it grows quite rapidly, even $1-2 \mathrm{~cm}$ a day. The seeds ripen about 6-8 weeks later, are scattered by wind, water, man, animals, vehicles and farm machinery (Zaitoun et al., 1991; Manschadi et al., 1996; Lolas, 1996 and 1997; López-Granados and García-Torres, 1998) and in the top 0-15 cm of the soil can be highly numerous, as just mentioned, reaching particularly high values (Lolas, 1996).

After the seeds ripen, the flowering shoot dies, whereas the tubercle may continue living for several years if the host is polyennial (Dawoud, 1995).

\section{Physiological effects of parasitism}

These effects may differ in relation to the susceptibility of the host plant to the attacks of $O$. crenata (Castillejo et al., 2004).

The removal of water, mineral ions, metabolites and hormones by the parasite gives rise to metabolic changes in the host which can either be interpreted as a defence against the parasite or as a stimulus to encourage its presence. Increases in iron in the faba bean seem to signal an ability to regulate the quantity and distribution of IAA in favour of Orobanche (Hassan et al., 1991). The accumulation in the parasite of mineral ions and sugars accentuates its sink behaviour, which following pseudo root growth, becomes dominant in the host-parasite system. In particular the accumulation of potassium:

- lowers water potential thus allowing the parasite to remove water from the host (Press et al., 1990), which, also due to reduced absorption by the parasite roots (Whitney, 
1972), shows signs of withering even in relatively highly moist soil;

- favours the translocation of the host's metabolites towards the parasite (Salisbury and Ross, 1996);

- eases host phloem discharge;

- determines the biosynthesis of "compatible solutes" in the parasite. The first metabolic stage in producing these solutes is through the hydrolysis of sucrose in glucose and fructose. Glucose is consumed by the whole metabolism whereas fructose is converted into mannitol, which contributes to lowering osmotic potential without denaturing the enzymes (Stewart et al., 1984). Osmoregulation by the parasite allows it to absorb water even at very low water potentials and therefore to complete the cycle even under drought conditions.

\section{Morphological, biological and productive effects of parasitism}

The sink effect of the parasite on the host plant is very negative and apart from withering, there are morphological, biological and productive modifications which are generally more accentuated the more precocious and virulent the attacks. Among those most commonly noted is premature yellowing of the leaves of the lower half of the shoots (the most manifest symptom in late attacks), slowing of growth and the incomplete phenological development of the plant, scarce flowering and setting, and curtailment of faba grain yield. The latter varies from 5 to $100 \%$ and it correlates positively with the soil seedbank and the number of emerged shoots (Linke and Saxena, 1991; Zaitoun et al., 1991), with higher values where water and minerals are less available (in these conditions, in fact, the host suffers all the more from competition with the parasite) and is determined almost exclusively by a reduction in the number of pods per plant.

\section{Means of Control}

Controlling $O$. crenata is by no means easy mostly because of:

- its ability to produce numerous seeds even in adverse environmental conditions;
- its ease of seed dissemination;

- the ability of seeds to remain viable for a long time and to require only one external stimulant for germination;

- the close parasite-host connection;

- the lack of economical, practical, efficient, selective and eco-compatible means of control. According to some authors, the development of effective control strategies depends on a better knowledge of parasite biology and physiology (Kuijt, 1969; Kasasian, 1973; Linke, 1992; Lutzeyer et al., 1994).

Of the numerous means of control adopted to date (Ciferri, 1955; Sauerborn et al., 1987; Lòpez-Granados et al., 1997), some occur before the infestation sets in (preventative), others afterwards (curative or therapeutic). Setting aside initiation, they are usually divided into agronomic, chemical, physical and biological (Weldeghiorghis, 1998) and they can be deployed singularly or in combination (Pieterse et al., 1992).

\subsection{Agronomic means}

These are almost all preventative means; in general, they are not very effective and insufficiently studied. Manual removal or destruction of the shoots just after emergence or, anyway, before the seeds ripen are the oldest practices and still in use in developing countries. Already by 1767 , it was estimated that in the 12 years needed to free Tuscany (Italy) of the infestation, and during the 1920s the main incentive for control was a reward of $£ 200.1 \mathrm{t}^{-1}$ of shoots $(\mathrm{Ci}-$ ferri, 1955). Resorting to this was quite labour costly, and did not appreciably attenuate the parasite's effect on host plant growth or production (Kharrat and Halila, 1996). Upon shoot emergence, the tubercle has already accumulated over $90 \%$ of dried substances and so the damage is substantially done. The opportune removal of the shoots, nevertheless, does not allow the parasite seeds to ripen, and therefore, augment the seedbank. A similar effect is obtained by ploughing in the infested crop before the parasite seeds ripen.

Other agronomic means of control entail:

- the use of host species seed absolutely free of Orobanche seeds;

- the adoption of a succession of crops with a return to the host species in the same soil after long periods, whose effectiveness can be 
reduced by the long life span of the parasite seeds due to their dormancy during the absence of the host plants (Krishnamurthy and Rao, 1976; Al-Menoufi, 1991);

- the reduction of Orobanche soil seedbank with the use of normal hosts, e.g. faba bean, pea, lentil, that stimulate the parasite to germinate and develop, but are destroyed before parasite seed production - or "trap crops" - false hosts, e.g. flax (Linum usitatissimum L.), basil (Ocymum basilicum L.) and coriander (Coriandrum sativum L.), which also stimulate parasite germination, but do not permit attachment or parasite development (Al-Menoufi, 1991; Khalaf 1992; Parker and Riches, 1993; Schnell et al., 1994);

- the intercropping of host species (faba bean, pea, chickpea, lentil, etc.) with lupin (Lupinus termis Forsk.), turnip (Brassica rapa L.), fenugreek (Trigonella foenum-graecum, L.), oat (Avena sativa L.) etc., whose root excretions reduce $O$. crenata seed germination by allelopathic mechanisms and therefore its attacks (Al-Menoufi et al., 1996; Bakheit et al., 2002; Rubiales et al., 2004; Fernàndez-Aparicio et al., 2006; Fernàndez-Aparicio et al., 2007a; Fernàndez-Aparicio et al., 2007b; Evidente et al., 2007);

- early spring sowing (for pea from the end of February to the first 10 days of April in Northern Italy) which would allow the crops to ripen before the high summer temperatures interrupt the parasite seeds' dormancy;

- late autumn sowing (for faba bean from the end of November to mid December in Sicily - Southern Italy) to reduce the period of highest susceptibility of the host plant in the winter season, when the soil temperature is lower than the optimal temperature for germination of $O$. crenata seeds $\left(15-20{ }^{\circ} \mathrm{C}\right)$;

- sowing the host seeds at the bottom of 25$30 \mathrm{~cm}$ furrows since a root located that deep is unlikely to encounter many germinable parasite seeds (Krishnamurthy et al., 1987);

- increasing of sowing density to decrease the number of $O$. crenata attachments per plant which does not always lead to a significant increase in grain yield (Pieterse and Aalders, 1986; Manschadi et al., 1997);

- the use of irrigation, e. g. drop irrigation, which does not facilitate parasite seed diffusion (Cubero and Moreno, 1979).

\subsection{Chemical means}

Of the numerous herbicides studied, imazethapyr and glyphosate have aroused interest (Kasasian, 1973; Schmitt et al., 1979; Jacobsohn and Kelman, 1980; Americanos, 1983; Kukula and Masri, 1984; Mesa-Garcìa et al., 1984; Garcìa-Torres et al., 1991; Jacobsohn and Eldar, 1992; García-Torres et al., 1996). The efficacy of glyphosate varies according to environmental, biological and technical conditions (El-Masry et al., 1991; Nadal et al., 2005). In faba bean infected with $O$. crenata at the predominant stages of already visible shoot bud or of well-developed shoot and vestigial roots, excellent control was achieved with a single glyphosate application of $60 \mathrm{~g} \mathrm{ha}^{-1}$ applied with an experimental sprayer $2 \mathrm{~m}$ wide, furnished with SS8001 nozzles delivering $1751 \mathrm{ha}^{-1}$ at $3 \mathrm{~kg} \mathrm{~cm}^{-2}$. At later stages of development with the shoot emerged from the shoot bud, its susceptibility to glyphosate decreases (Mesa-García and Garcìa-Torres, 1985). The disparate effectiveness of glyphosate in relation to the parasite growth stage at the time of application is probably due to a dissimilar glyphosate quantities transported into the parasite. It was found that the best translocation of glyphosate from the host to the parasite occurs when O. crenata is in the turbercle stage (Müller and Distler, 1991).

Glyphosate also ensured positive effects in narbon vetch (Vicia narbonensis L.) and in parsley (Petroselinum crispum L.) with dose applications of $35-67 \mathrm{~g} \mathrm{ha}^{-1}$ (Nadal et al., 2008). In this latter species, $O$. crenata and $O$. aegyptiaca were completely controlled by split foliar application of imazapic at 2.5-5.0 $\mathrm{g} \mathrm{ha}^{-1}$ or glyphosate at 36-72 $\mathrm{g} \mathrm{ha}^{-1}$, applied on 5-7 leaf parsley before the first cutting and on the new growth after each cutting (Goldwasser et al., 2003).

The use of transgenic and mutant crops with target-site herbicide resistance is therefore a most promising solution for Orobanche and Striga infestation in many crops, and may fully control the parasite without affecting the crop and its yield (Abayo et al., 1998; Joel et al., 1995b, 2000; Surov et al., 1997).

In vitro, significant reductions in seed germination and growth of $O$. crenata have been obtained using nitrogen fertilizers, particularly those with ammonia and urea (Kukula and Masri, 1984; Pieterse, 1991; Van Hezewiik et al., 
1991), as well as with soil fumigation with ethylene bromide and methyl bromide (Zahran, 1970; Foy et al., 1989). It should be noted that methyl bromide fumigation, subject to increasing restrictions due to environmental risks, negatively affects the Rhizobium spp. activities (Parker and Riches, 1993).

To provoke parasite seed germination without host plant stimulation, adding gibberellins and compounds like strigol to the soil is hardly effective, probably due to the reduced stability of their molecules (Mangnus et al., 1992) depending on soil characteristics like $\mathrm{pH}$ and water content. On the contrary and worthy of further investigation, it appears that paclobutrazol, an inhibitor of gibberellin biosynthesis, significantly reduces the germination of $O$. cumana seed (Joel et al., 1991).

While having no effect on $O$. crenata, feeding the host plant kinetin (cytokinin is usually strongly removed by the host's parasite) increases growth and, if done during the pod growth phase, significantly increases faba bean production (El-Ghamrawy and Neumann, 1991).

\subsection{Physical means}

During the last 30 years, interest has been growing in soil solarization, warm mulching or solar pasteurization, also for its ecocompatibility. Research in different environments concluded that it significantly reduces or wipes out attacks by $O$. crenata (Mesa-García and García-Torres, 1986; Haidar and Sidahmed, 2000; Mauromicale et al., 2001; 2005; Restuccia et al., 2001; 2005; 2007) especially if combined with chicken manure and repeated for many consecutive years and that its effects continue to be appreciable into the following year (Sauerborn et al., 1989; Restuccia et al., 2005).

Soil solarization, despite its efficacy and ecocompatibility, is not widespread. The reasons for this have not been sufficiently studied. It seems, however, that they lie in the fact that during treatment (usually for periods lasting from 6-8 weeks) the soil cannot be used which renders it uneconomical.

\subsection{Biological means}

This tactic foresees the use of antagonistic agents and the cultivation of resistant/tolerant biotypes. The antagonistic agents are numerous (Del Serrone and Quacquarelli, 1988; Sauerborn and Kroschel, 1996; Sauerborn, 1993; Klein and Kroschel, 2002; Zermane et al., 2004; Sauerborn et al., 2007) and there is continuing interest in some phytopathogenous fungi (Fusarium oxisporum, Urocladium botrytis, Mirothecium verrucasia, Trichoderma harzianum, T. viride) and their phytotoxins (Müller-Scharer et al., 2000; Abdel-Kader et al., 2001; El-Kassas et al., 2005; Müller-Stover and Kroschel, 2005), as well as in the diptera Phytomyza orobanchia, which lays its eggs inside the capsules where their larvae can destroy up to $90 \%$ of the seeds (Sauerborn, 1991a; Amsellem et al., 2001) and bacteria isolated from the rhizosphere of faba bean, available to counteract $O$. crenata (Mabrouk et al., 2007). It should be noted, however, that the mycoherbicide strategy has drawbacks because of high cost and legislative restrictions. In addition, under standard cultivation conditions, the effectiveness of antagonist agents was generally lower than its potential because of unfavourable environmental conditions and interference from some agricultural practices (succession of crops, ploughing, burying or burning crop residues, plant health treatments, etc.).

Resistant biotypes have not always proved positive because of their polygenetic nature and the partial levels of parasite resistance verified (Romàn et al., 2002). A moderately resistant faba line has been identified, F 402, which is already used in a genetic improvement programme (Nassib et al., 1979, 1982, 1984), and several accessions with varying levels of parasite resistance (Cubero, 1991). F 402 was later released as cultivar Giza 402 (Nassib et al., 1979; 1982). Selected from Giza 402 under field conditions, VF 1017 was crossed with Spanish cultivars to produce Baraca (Cubero et al., 1994; Manshadi et al., 1997). Giza 402 and Baraca represent the only partially resistant cultivars currently available. Recently, appreciable levels of resistance to $O$. crenata attacks were observed in some accessions of narbon vetch (Nadal et al., 2007), lentil (Fernàndez-Aparicio et al., 2008a), chickpea (Rubiales et al., 2004) and pea (Rubiales et al., 2005). Partial resistance in pea is highly influenced by environmental conditions and is the consequence of a combination of several resistance mechanisms and may become apparent at different times during the parasite's biological cycle (Nassib et al., 1979; Manshadi et al., 1997; Pérez-de-Luque et al., 2008). 
Recently these mechanisms were divided into three groups: pre-attachment, prehaustorial and posthaustorial (Pérez-de-Luque et al., 2008).

The pre-attachment mechanisms take place in the first stage of the infection process (germination of parasite seeds and chemical guidance of the germ tube towards host root). Three of these mechanisms are as follows:

- reduced production of lateral roots, more compact root system and low root length density (RLD), observed in faba bean (Nassib et al., 1979; Manshadi et al., 1997);

- low production of exuded germination stimulants from the host root, found in some accessions of a range of legumes including faba bean, vetches, peas, chickpea and grass peas (Aalders and Pieters, 1986; Ter Borg, 1999; Rubiales et al., 2003a; Rubiales et al., 2004; Pérez-de-Luque et al., 2005a; Rubiales et al., 2005; Sillero et al., 2005);

- host production of root inhibitory metabolite capable of decreasing $O$. crenata seed germination of which in fenugreek the most active is a new monosubstituted trioxazonane, characterized as the 2-butyl-[1,4,7,2] trioxazonane and named trigoxazonane (Evidente et al., 2007; Fernàndez-Aparicio et al., 2008b).

The prehaustorial mechanisms are involved when the parasite establishes contact with the host root, penetrating into the host tissues and forming vascular connections with the host. The intrusive Orobanche cells can be stopped at three different levels (Pérez-de-Luque et al., 2008):

- in the cortex, observed in resistant pea, faba bean, chickpea, etc. (Rubiales et al., 2003a; Pérez-de-Luque et al., 2005b; EchevarríaZomeño et al., 2006) and due to the reinforcement of the host cell walls by protein cross-linking callose depositions and suberisation (Echevarría-Zomeño et al., 2006; Pérez-de-Luque et al., 2006a, 2007) and probably due to the accumulation and excretion of toxic phenolic compounds into the apoplast at the infection point (Serghini et al., 2001; Echevarría-Zomeño et al., 2006; Lozano-Baena et al., 2007);

- at the endodermis, observed in vetch and faba bean and due to the lignification of endodermal and pericycle cell walls (Pérez-deLuque et al., 2005b, 2007);

- inside the central cylinder, observed in Medicago truncatula (Lozano-Baena et al., 2007) and probably due to the accumulation of phenolic compounds which are toxic for the parasite (Pérez-de-Luque et al., 2006c; Lozano-Baena et al., 2007).

The posthaustorial mechanisms are involved after the parasite has developed a haustorium and established connection with the host, becoming one with the plant, acting as a sink for water and nutrients (Pérez-de-Luque et al., 2008). The necrosis and death of established Orobanche tubercles is, in some cases, related to the presence of gel or gum-like substances within host vessels (Pérez-de-Luque et al., 2005b; Pérez-de-Luque et al., 2006b) or to the production of toxic host compounds (phenolics) delivered into the parasite through the vascular system (Pérez-de-Luque et al., 2006c; Lozano-Baena et al., 2007).

\subsection{Integrated control}

The results showed that single methods are not sufficient for effective parasite control and suggest developing integrated control methods for different ecological and socio-economic conditions. The trials were conducted almost exclusively on faba bean grown in the Mediterranean region. The suggested strategies provide a combination of seed treatments with benomyl, the application of calcium-cyanamide and glyphosate (Petzoldt, 1979); of tillage, fertilizer and glyphosate (Kukula and Masri, 1984); of delayed sowing and herbicide treatment (glyphosate rate of $2 \times 80 \mathrm{~g} \mathrm{ha}^{-1}$ or imazaquin at $2 \times 40 \mathrm{~g} \mathrm{ha}^{-1}$ ); of delayed sowing, herbicide treatment (glyphosate treatment at a rate of $2 \times 80 \mathrm{~g} \mathrm{ha}^{-1}$ or imazaquin at $2 \times 40 \mathrm{~g} \mathrm{ha}^{-1}$ ) and soil solarization (Linke and Saxena, 1991); of resistant cultivars and early sowing (Pérez-de-Luque et al., 2004). During the trials conducted by Linke and Saxena (1991), combining herbicide treatment with delayed sowing proved successful in Orobanche controls with the highest economic efficiency. Resistant cultivars allow early sowing (with low O. crenata attack), thus avoiding yield losses due to the short crop cycle with late sowing (Pérezde-Luque et al., 2004).

\section{Conclusions}

Especially in the last quarter of the previous century, O. crenata was the subject of much research, mainly conducted in Europe (Spain, 
Germany, Netherlands, UK, Italy, France, etc.), the Middle East (Israel, Syria, the Lebanon, etc.), Northern Africa (Egypt, Tunisia, Morocco, etc.) and Asia (India, Turkey, Nepal, etc.). However, the overall results do not identify decisive solutions for controlling this holoparasitic phanerogam. In fact, even those solutions considered promising by researchers have not yet been widely used for various reasons (high cost compared to host crop income, risk of environmental pollution, variable effectiveness in relation to environmental conditions, etc.). On the other hand, the results have increased our knowledge of parasite biology, host resistance mechanisms and the effectiveness of many control methods, all of which are certainly significant for the development of future research programmes. With reference to the $O$. crenata control, there may be the opportunity for further study:

- by agronomic means, especially if they are able to reduce the seedbank;

- by use of systemic herbicides, which, through the host plant, eliminates the parasite during the first stages of its biological cycle when it is developing underground;

- by solarization, in relation to the film characteristics, the frequency and duration of treatment, organic manuring;

- by host resistant or tolerant cultivars even in environments different to the one from which they originated;

- by strategies of integrated control.

\section{References}

Aalders A.J.G., Pieters R. 1986. Plant vigour as a misleading factor in the search for resistance in broad bean to Orobanche crenata. In: ter Borg S.J. (ed.): Proceedings of the International Workshop on Biology and Control of Orobanche. Wageningen, The Netherlands: LH/VPO, 140-149.

Abayo G.O., English T., Eplee R.E., Kanampiu F.K., Ransom J.K., Gressel J. 1998. Control of parasitic witchweed (Striga sp.) on corn (Zea mays) resistant to acetolactate synthase inhibitors. Weed Sci., 46:459-466.

Abdel-Kader M.M., El-Mougy N.S. 2001. Evaluation of different approaches of mycoherbicidal application for controlling Orobanche crenata in pea field. Egypt. J. of Phytopathol., 29, 2:69-82.

Aber, M., 1984. Cytophysiological aspects of or Orobanche crenata Forsk. parasitizing Vicia faba L. In: Third International Symposium on Parasitic Weeds, Aleppo.
Aber M., Sallé G. 1983. A histological and cytochemical study of the seeds and procaulome of Orobanche crenata Forsk. Graine et procaulome d'Orbanche crenata Forsk: etude histocytologique et cytochimique. Can. J. Bot., 61:3302-3313.

Abu Sbaih H.A., Jury S.L. 1994. Seed micromorphology and taxonomy in Orobanche (Orobanchaceae). Fl. Medit., 4:41-48.

Abu-Shakra S., Maih A.A., Saghir A.R. 1970. Germination of seed of branched broomrape (Orobanche ramosa L.). Horticultural Res., 10:119-124.

Al-Menoufi O.A. 1991. Crop rotation as a control measure of Orobanche crenata in Vicia faba fields. In: Wegmann K., Musselmann L.J. (eds.): Progress in Orobanche Research. Proceeding of the International Workshop on Orobanche Research, 19-22 August 1989, Obermarchtal FRG, 241-247.

Al-Menoufi O.A., Adam M.A., El Safwani N.A. 1996. Biological and chemical inhibition of Orobanche seed germination. In: Moreno M.T., Cubero J.I., Berner D., Joel D.M., Musselmann L.J., Parker C. (eds.): Advances in Parasitic Plant Research. Junta de Andalucìa, Sevilla, Spain, 417-423.

Americanos P.G. 1983. Control of Orobanche in broad beans. Nicosia, Cyprus: Agricultural Research Institute. Technical Bulktin, 50:4.

Amsellem Z., Barghouthi S., Cohen B., Goldwasser Y., Gressel J., Hornok L., Kerenyi Z., Kleifeld Y., Klein O., Kroschel J., Sauerborn J., Muller-Stover D., Thomas H., Vurro M., Zonno M.C. 2001. Recent advances in the biocontrol of Orobanche (broomrape) species. BioControl, 46:211-228.

Baird W.M.V., Riopel J.L. 1985. Surface characteristics of root and haustorial hairs of parasitic Scrophulariaceae. Bot. Gaz., 146:63-69.

Bakheit B.R., Allam A.Y., Galal A.H. 2002. Intercropping faba bean with some legume crops for control of Orobanche crenata. Acta Agron. Hung., 50:1-6.

Bar-Nun N., Mayer A.M. 1993. Preconditioning and germination of Orobanche seeds: respiration and protein synthesis. Phytochemistry, 34:39-45.

Carter R.J., Cooke D.A., Barker W.R., Csurhes S.M. 1996. Occurrence and control of Striga, Orobanche and Cuscuta in Australia. In: Moreno M.T. et al. (eds.): Advances in Parasitic Plant Research, Junta de Andalucía, Sevilla, 801-808.

Castillejo M.A., Amiour N., Dumas-Gaudot E., Rubiales D., Jorrìn J.V. 2004. A proteomic approach to studying plant response to crenate broomrape (Orobanche crenata) in pea (Pisum sativum). Phytochemistry, 65:1817-1828.

Ciferri R. 1955. Manuale di Patologia vegetale (Malattie delle piante agrarie italiane). Tomo II. Società Editrice Dante Alighieri.

Cubero J.I., Moreno M.T. 1979. Agronomical control and sources of resistance in Vicia faba to Orobanche spp. In: Bond D.A., Scarascia-Mugnozza G.T., Poulsen M.H. (eds.): Some current research on Vicia faba in 
Western Europe. Luxembourg: Commission of the European Communities, 41-90.

Cubero J.I. 1983. Parasitic diseases in Vicia faba L. with special reference to broomrape (Orobanche crenata Forsk.). In: Hebblethwaite P.D. (ed.): The Faba Bean (Vicia faba L.), 493-519, Butterworths, London, UK.

Cubero J.I. 1991. Breeding for resistance to Orobanche species: A review. In: Wegmann K., Musselmann L.J. (eds.): Progress in Orobanche Research. Proceeding of the International Workshop on Orobanche Research, 19-22 August 1989, Obermarchtal FRG, 257-277.

Cubero J.I., Pieters A.H., Khalil S.A., Sauerborn J. 1994. Screening techniques and sources of resistance to parasitic angiosperms. In: Muehlbauer F.J., Kaiser W.J. (eds.): Expanding the Production and the Use of Cool Season Food Legumes The Netherlands, 333-345. Kluwer Academic Publishers.

Dawoud D.A. 1995. Autecological studies on phytoparasites of the genera Alectra, Orobanche and Striga with special reference to their early developmental stages. PLITS 13, Margraf Verlag, Weikersheim, FRG, 112.

Del Serrone P., Quacquarelli A. 1988. Lotta biologica contro le infestanti. La difesa delle colture tra chimica ed ecologia. L'Italia Agricola, 12:333-338.

Diaz J., Norambuena H. 2001. Parasitism and phenology of Orobanche ramosa on tomato. In Fer A., Thalouarn P., Joel D.M., Musselman L.J., Parker C., Verkleij J.A.C. (eds.): Proceedings of the Seventh International Parasitic Plant Symposium, Faculté des Sciences, Nantes, France, 47.

Dörr I., Kollman R. 1974. Structural features of parasitism of Orobanche. I: Growth of the haustorial cells within the host tissue. Protoplasma, 80:245-249.

Dörr I., Kollman R. 1975. Structural features of parasitism of Orobanche. II. The differentiation of assimilate conducting elements within the haustorium. Protoplasma, 83:185-199.

Dörr I., Kollman R. 1976. Structural features of parasitism of Orobanche. III. The differentiation of xylem connection of $O$. crenata. Protoplasma, 89:235-239.

Dörr I., Kollman R. 1995. Symplasmic sieve element continuity between Orobanche and its host. Bot. Acta, 108:47-55.

Echevarría-Zomeño S., Pérez-De-Luque A., Jorrín J., Maldonado A.M. 2006. Pre-haustorial resistance to broomrape (Orobanche cumana) in sunflower (Helianthus annuus): cytochemical studies. J. Exp. Bot., 57:4189-4200.

Edwards W.G.H. 1972. Orobanche and other plant parasite factors. In: Harbome J.B. (ed.): Phytochemical Ecology, 235-248. Academic Press, London.

Edwards W.G.H., Hiron R.P., Mallet A.I. 1976. Aspects of germination of Orobanche crenata seeds. Z. Pflanzenphysiol, 180:105-1 11.

El-Basyouni S.Z.M. 1979. Phenolic germination inhibitors from seeds of Orobanche crenata. Proceedings of the Third Conference on the Biological As- pects of Saudi Arabia University of King Faisal, January 24-27, Al-Ahsa, Saudi Arabia.

El-Ghamrawy N., Salem S.M., Neumann K.H. 1990. Nature of root exudates of Vicia faba plants in relation to induction of Orobanche crenata seed germination. Angew. Bot., 64:215-224.

El-Ghamrawy N., Neumann K.H. 1991. Some physiological aspects of Orobanche crenata parasitsm on $\mathrm{Vi}$ cia faba. In: Wegmann K., Musselmann L.J. (eds.): Progress in Orobanche Research. Proceeding of the International Workshop on Orobanche Research, 1922 August 1989, Obermarchtal FRG, 134-146.

El-Kassas M., Karem El-Din Z., Beale M.H., Ward J.L., Strange R.N. 2005. Bioassay-led isolation of Myrothecum verrucaria and verrucarin A as germination inhibitors of Orobanche crenata. Weed Res., 45:212-219.

El-Masry R., Naguib N.A., El-Baz F.K. 1991. The influence of glyphosate on the host-parasite relationship between Vicia faba and Orobanche crenata. In: Wegmann K., Musselmann L.J. (eds.): Progress in Orobanche Research. Proceeding of the International Workshop on Orobanche Research, 19-22 August 1989, Obermarchtal FRG, 215-225.

Evenari M. 1949. Germination inhibitors. Bot. Rev., 15:153-194.

Evidente A., Fernàndez-Aparicio M., Andolfi A., Rubiales D., Motta A. 2007. Trigoxazonane, a monosubstituted trioxazonane by Trigonella foenum-graecum root exudate, inhibiting agent of Orobanche crenata seed germination. Phytochemistry, 68:2487-2492.

Fernàndez-Aparicio M., Sillero J.C., Moreno M.T., Rubiales D. 2006. Orobanche crenata infection on faba bean can be reduced in crop mixtures. In: Avila C.M., Cubero J.I., Moreno M.T., Suso M.J., Torres A.M. (eds.): International Workshop on Faba Bean Breeding and Agronomy, 25-27 October 2006, Córdoba, Spain, Junta de Andalucìa, Sevilla, 148-150.

Fernàndez-Aparicio M., Sillero J.C., Rubiales D. 2007a. Intercropping with cereals reduces infection by Orobanche crenata in legumes. Crop Prot., 26:11661172.

Fernàndez-Aparicio M., Emeran A.A., Rubiales D. 2007b. Control of Orobanche crenata in legumes intercropped with fenugreek (Trigonella foenum-graecum). Crop. Prot., 27, 3-5:653-659.

Fernàndez-Aparicio M., Sillero J.C., Pérez-de-Luque A., Rubiales D. 2008a. Identification of sources of resistance to crenata broomrape (Orobanche crenata) in Spanish lentil (Lens culinaris) germplasm. Weed Res., 48:85-94.

Fernàndez-Aparicio M., Andolfi A., Evidente A., Pérezde-Luque A., Rubiales D. 2008b. Fenugreek root exudates show species-specific stimulation of Orobanche seed germination. Weed Res., 48:163-168.

Fiori A. 1969. Nuova Flora Analitica d'Italia, vol. 2, 378392. Edagricole, Bologna.

Foy C.L., Jain R., Jacobsohn R. 1989. Recent approaches for chemical control of broomrape (Orobanche spp.). Weed Sci., 4:123-152. 
García-Torres L., López-Granados F., Saavedra M. 1991. New herbicides for broomrape (Orobanche crenata) control in faba bean (Vicia faba). In: Wegmann K., Musselmann L.J. (eds.): Proceeding International Workshop on Orobanche Research. Tübingen, Germany, 200-208.

García-Torres L., Jurado-Expósito M., Díaz Sánchez J., Castejón-Muñoz M., López-Granados F. 1996. Grow good peas. Control of anthracnose and broomrape. Seed treatment. (in Spanish). Agricultura, Revista Agropecuaria, 65:755-759.

Goldwasser Y., Eizenberg H., Golan S., Kleifeld Y. 2003. Control of Orobanche crenata and Orobanche aegyptiaca in parsley. Crop Prot., 22:295-305.

Grenz J.H., Sauerborn J. 2007. Mechanism limiting geographical range of the parasitic weed Orobanche crenata. Agric., Ecosyst. Environ., 122:275-281.

Greuter W., Burdet H.M., Long G. 1989. Med-Cecklist. Dicotyledones (Lauraceae-Rhamnaceae), vol. 4, 258. Editions des Conservatoire et Jardin botaniques de la Ville de Genève. Med-Cecklist Trust of OPTIMA, Genève.

Haidar M.A., Sidahmed M.M. 2000. Soil solarization and chicken manure for the control of Orobanche crena$t a$ and other weeds in Lebanon. Crop Prot., 19:169173.

Hassan H.M., El-Basyouni S.Z., El-Ghamrawy N. 1980. Effect of flax root exudate, growth regulating substances (GA3, IAA and Kinetin) and preconditioning treatments on the germination of Orobanche crenata seeds. Cairo (Egypt), 17.

Hassan H.M., Kheir N.F., Harb E.Z., Ghobashy A.M. 1991. The effect of CCC and GA3 on the nutritional status of tomato plants parasitized by Orobanche ramosa. In: Wegmann K., Musselmann L.J. (eds.): Progress in Orobanche Research, Proceeding of the International Workshop on Orobanche Research, 1922 August 1989, Obermarchtal FRG, 80-91.

Hsiao A.I., Worsham A.D., Moreland D.E. 1988. Effects of chemicals often regarded as germination stimulants on seed conditioning and germination of witchweed (Striga asiatica). Ann. Bot., 62:17-24.

Jacobsohn R., Kelman Y. 1980. Effectiveness of glyphosate in broomrape (Orobanche spp.) control in four crops. Weed Sci., 28:692-99.

Jacobsohn R., Eldar E. 1992. Imazethapyr for broomrape control in peas. Phytoparasitica, 20:345.

Joel D.M., Back A., Kleifeld Y., Gepstein S. 1991. Seed conditioning and its role in Orobanche seed germination: inhibition by paclobutrazol. In: Wegmann K., Musselmann L.J. (eds.): Progress in Orobanche Research, Proceeding of the International Workshop on Orobanche Research, 19-22 August 1989, Obermarchtal FRG, 147-156.

Joel D.M., Losner-Goshen D. 1994. The attachment organ of the parasitic angiosperms Orobanche cumana and O. aegyptiaca and its development. Can. J. Bot., 72:564-574.
Joel D.M., Steffens J.C., Matthews D.E. 1995a. Germination of weedy root parasites. In: Kigel J., Galili G. (eds.): Seed Development and Germination. Marcel Dekker, Inc, New York, 567-598.

Joel D.M., Kleifeld Y., Losner-Goshen D., Herzlinger G., Gressel J. 1995b. Transgenic crops to fight parasitic weeds. Nature, 374:220-221.

Joel D.M., Losner-Goshen D., Goldman-Guez T., Portnoy V.H. 1998. The Haustorium of Orobanche. In: Wegmann K., Musselmann L.J., Joel D.M. (eds.): Current Problems in Orobanche Research. Proceedings of the Fourth International Workshop on Orobanche. Albena, Bulgaria, 101-106.

Joel D.M. 2000. The long-term approach to parasitic weeds control: manipulation of specific developmental mechanisms of the parasite. Crop Prot., 19:753-758.

Joel D.M., Plakhin D., Creange P., Dupuis J.M., Kamoda J., Gressel J. 2000. Broomrape (Orobanche aegyptiaca Pers.) control using asulam-resistant seeds coated with asulam. WSSA Abstracts. 137.

Joel D.M., Hershenhorn Y., Eizenberg H., Aly R., Ejeta G., Rich P.J., Ransom J.K., Sauerborn J., Rubiales D. 2007. Biology and management of weedy root parasites. In: Janick J. (ed.): Hortic. Rev., 33:267-350. John Wiley and Sons Inc, New York.

Kardy A.E.R., Tewfic H. 1956. Seed germination in Orobanche crenata Forsk. Svensk Bot. Tidsk., 50:270286.

Kasasian L. 1973. Miscellaneous observation on the biology of Orobanche crenata and Orobanche aegyptiaca. Proceedings of the European Weed Research Council Symposium on Parasitic Weeds, Malta, 224230.

Kebreab E., Murdoch A.J. 1999. Predicting Orobanche seed longevity for better weed management in legumes. Grain Legumes, 23, 1st quarter: 8-9.

Khalaf K.A. 1991. Determination of the viability of different Orobanche crenata seed origins, in relation to their metabolic germination activity. In: Wegmann K., Musselmann L.J. (eds.): Progress in Orobanche Research, Proceeding of the International Workshop on Orobanche Research, 19-22 August 1989, Obermarchtal FRG, 102-109.

Khalaf K.A. 1992. Evaluation of the biological activity of flax as a trap crop against Orobanche parasitism of Vicia faba. Trop.Agric., 69:35-38.

Kharrat M., Halila M.H. 1996. Control of Orobanche fetida on Vicia faba: Comparison between different control measures - advances in parasitic plant research. In: Moreno M.T., Cubero J.I., Berner D., Joel D.M., Musselmann L.J., Parker C. (eds.): Proceedings of the Sixth International Symposium on Parasitic Weeds. Còrdoba, Spain, 734-737.

Klein O., Kroschel J. 2002. Biological control of Orobanche spp. with Phytomyza orobanchia, a review. BioControl, 47:244-276.

Kreutz C.A.J. 1995. Orobanche. The European broomrape species. A field guide. Vol. 1. Central and North- 
ern Europe. Natuurhistorisch Genootschap in Limburg.

Krishnamurthy S., Rao U.M. 1976. Control of Orobanche through crop rotation. Indian Farm., 25:23.

Krishnamurthy G.V.G., Nagarajan K., Lal R. 1987. Studies on longevity and depth of emergence of broomrape in tobacco fields. Indian J. Weed Sci., 38:41.

Kuijt J. 1969. The Biology of Parasitic Flowering Plants. University of California Press, Berkeley, USA, 246.

Kukula S., Masri K.H. 1984. Integrated cultural practices and chemical control of Orobanche crenata in faba bean. In Parker C., Musselmann L.J., Poltdll R.M., Wilson A.K. (eds.): Proceeding of the $3^{\text {rd }}$ International Symposium on Parasitic Weeds. Aleppo, Syria: ICARDA, 256-261.

Kukula S., Masri H. 1985. A greenhouse technique for screening faba beans (Vicia faba L.) for resistance to Orobanche. Fabis Newletter, 12:20-23.

Linke K.H. 1987. Untersuchungen uber Keimung und Jugendentwicklung von Striga and Orobanche. Verlag Josef Margraf., Weikersheim, FRG, 95.

Linke K.H., Saxena M.C. 1991. Study on viability and longevity of Orobanche seed under laboratory conditions. In: Wegmann K., Musselmann L.J. (eds.): Progress in Orobanche Research. Proceeding of the International Workshop on Orobanche Research, 1922 August 1989, Obermarchtal FRG, 110-114.

Linke K.H. 1992. Biology and control of Orobanche in legume crops. Plits, 10:66.

Lolas P.C. 1996. Sub-group collaborative study on broomrape. 1995-1996 report. Bulletin d'Information - CORESTA, 3/4:47-51.

Lolas P.C. 1997. Sub-group collaborative study on broomrape. Bulletin d'Information - CORESTA, 3:79-85.

Lòpez-Granados F., Garcìa-Torres L. 1996. Effects of environmental factors on dormancy and germination of crenate broomrape (Orobanche crenata). Weed Sci., 44:284-289.

Lòpez-Granados F., Garcìa-Torres L. 1993. Seed bank and other demographic parameters of broomrape (Orobanche crenata Forsk.) populations in faba bean (Vicia faba L.). Weed Res., 33:319-327.

Lòpez-Granados F., Garcìa-Torres L., Díaz Sánchez J. 1997. Bioeconomic model for crenate broomrape (Orobanche crenata) in broad bean (Vicia faba) under different management strategies. (in Spanish). Proceedings Sociedad Española de Malherbologia Congresso, Valencia, 1997.

Lòpez-Granados F., Garcìa-Torres L. 1998. Short- and long-term economic implications of controlling crenate broomrape (Orobanche crenata Forsk.) in broad bean (Vicia faba L.) under various management strategies. Crop Prot., 17:139-143.

Lòpez-Granados F., Garcìa-Torres L. 1999. Longevity of crenate broomrape (Orobanche crenata) seed under soil and laboratory conditions. Weed Sci., 47:161-166.
Losner-Goshen D., Portnoy V.H., Mayer A.M., Joel D.M. 1998. Pectolytic activity by the haustorium of the parasitic plant Orobanche L. (Orobanchaceae) in host roots. Ann. Bot., 81:319-326.

Lozano-Baena M.D., Moreno M.T., Rubiales D., PérezDe-Luque A. 2007. Medicago truncatula as a model for non-host resistance in legume-parasitic plant interactions. Plant Physiol., 145:437-449.

Lutzeyer H.J., Kroschel J., Sauerborn J. 1994. Orobanche crenata in legume cropping farmers perception, difficulties and prospects of control - a case study in Morocco. In: Pieterse A.H., Verkleij J.A.C., Ter Borg S.J. (eds.): Biology and management of Orobanche. Proceedings of the Third International Workshop on Orobanche and related Striga research, Amsterdam, The Netherlands, Royal Tropical Institute, 433-441.

Mabrouk Y., Zourgui L., Sifi B., Delavault P., Simier P., Belhadj O. 2007. Some compatible Rhizobium leguminosarum strains in peas decrease infections when parasitised by Orobanche crenata. Weed Res., 47:44-53.

Mangnus E.M., Zwanenburg B. 1991. Design and synthesis of germination stimulants for seeds of Striga and Orobanche spp. In: Wegmann K., Musselmann L.J. (eds.): Progress in Orobanche Research. Proceeding of the International Workshop on Orobanche Research, 19-22 August 1989, Obermarchtal FRG, 157-166.

Mangnus E.M., Stommen P.L.A., Zwanenburg B. 1992. A standardized bioassay for evaluation of potential germination stimulants for seeds of parasitic weeds. J. Plant Growth Regul., 11:91-98.

Manschadi A.M., Kroschel J., Sauerborn J. 1996. Dry matter production and partitioning in the host-parasite association Vicia faba - Orobanche crenata. Angew. Bot., 70:224-229.

Manschadi A.M., Sauerborn J., Kroschel J., Saxena M.C. 1997. Effect of plant density on grain yield, rootlength density, and Orobanche crenata infestation in two faba bean genotypes. Weed Res., 37:39-49.

Marudarjan D. 1950. Note on Orobanche cernua Loefl. Current Sci., 19, 2:64-65.

Matusova R., Rani K., Verstappen F.W.A., Franssen M.C., Beale M.H., Bouwmeester H.J. 2005. The strigolactone germination stimulants of plant-parasitic Striga and Orobanche spp. are derived from the carotenoid pathway. Plant Physiol., 139:920-934.

Mauromicale G., Restuccia G., Marchese M. 2000. Germination response and viability of Orobanche crenata Forsk. seeds subjected to temperature treatment. Aust. J. Agr. Res., 51:579-585.

Mauromicale G., Restuccia G., Marchese M. 2001. Soil solarization, a non-chemical technique for controlling Orobanche crenata and improving yield of faba bean. Agronomie, 21:757-765.

Mauromicale G., Marchese M., Restuccia A., Sapienza O., Restuccia G., Longo A.M.G. 2005. Root nodulation and nitrogen accumulation and partitioning in legume crops as affected by soil solarization. Plant Soil, 271:275-284. 
Mayer A.M., Shain Y. 1974. Control of seed germination. Annu. Rev. Plant Phys., 25:167-193.

Mesa-García J., Haro A., García-Torres L. 1984. Phytotoxicity and yield response of broadbean (Vicia faba L.) to glyphosate. Weed Sci., 32:445-50.

Mesa-García J., García-Torres L. 1985. Orobanche crenata Forsk. control in Vicia faba (L.) with glyphosate as affected by herbicide rates and parasitic growth stages. Weed Res., 25:129-134.

Mesa-García J., García-Torres L. 1986. Effect of planning date on parasitism of broadbean (Vicia faba) by crenata broomrape (Orobanche crenata). Weed Sci., 34:544-550.

Mitich L.W. 1993. Orobanche-The Broomrapes. Weed Technol., 7:532-535.

Morozov I.V., Foy S.L., Westwood J.H. 2000. Small broomrape (Orobanche minor) and Egyptian broomrape (Orobanche aegyptiaca) parasitization of red clover (Trifolium pratense). Weed Technol., 14:312320 .

Müller F., Distler B. 1991. Translocation of glyphosate in the hostparasite system Vicia faba and Orobanche crenata. In: Wegmann K., Musselmann L.J. (eds.): Progress in Orobanche Research. Proceeding of the International Workshop on Orobanche Research, 1922 August 1989, Obermarchtal FRG, 226-233.

Müller-Schàrer H., Scheepens P.C., Greaves M.P. 2000. Biological control of weeds in European crops: recent achievements and future work. Weed Res., 40:83-98.

Müller-Stover D., Kroschel J. 2005. The potential of Ulocladium botrytis for biological control of Orobanche spp. Biol. Control, 33:301-306.

Musselman L.J. 1980. The biology of Striga, Orobanche, and other root parasitic weeds. Annu. Rev. Phytopathology, 18:463-89.

Nadal S., Moreno M.T., Cubero J.I., Rubiales D. 2005., Determinate faba bean young pod response to glyphosate and crenate broomrape (Orobanche crenata). J. Sustain. Agr., 25:19-27.

Nadal S., Cubero J.I., Moreno M.T. 2007. Sources of resistance to broomrape (Orobanche crenata Forsk.) in narbon vetch. Plant Breeding, 126:110-112.

Nadal S., Moreno M.T., Romàn B. 2008. Control of Orobanche crenata in Vicia narboriensis by glyphosate. Crop Prot., 27:873-876.

Nandula V.K. 1998. Selective control of Egyptian broomrape (Orobanche aegyptiaca Pers.) by glyphosate and its amino acid status in relation to selected hosts. $\mathrm{PhD}$ thesis, Faculty of the Virginia Polytechnic Institute and State University.

Nash S.M., Wilhelm S. 1960. Stimulation of broomrape seed germination. Phytopathology, 50:772-774.

Nassib A.M., Ibrahim A.A., Saber H.A. 1979. Broomrape (Orobanche crenata) resistance in broad beansbreeding work in Egypt. In: Hawtin G.C., Chancellor G.J. (eds.): Food Legume Improvement and Development, 133-135. IDRC, Ottawa, Canada.
Nassib A.M., Ibrahim A.A., Khalil S.A. 1982. Breeding for resistance to Orobanche. In: Hawtin G., Webb C. (eds.): Faba Bean Improvement, 199-206. Martinus Nijhoff, The Hague, The Netherlands.

Nassib A.M., Hussein A.H.A., El Reyes F.M. 1984. Effect of variety, chemical control, sowing date and tillage on Orobanche spp. infestation and faba bean yield. FABIS Newsl, 10:11-15.

Parker C., Riches C.R. 1993. Parasitic Weeds of the World: Biology and Control. CAB International, Wallingford, UK.

Pennypacker B.W., Nelson P.E., Wilhelm S. 1979. Anatomic changes resulting from the parasitism of tomato by Orobanche ramosa. Phytopathology, 69:741-748.

Pérez-de-Luque A., Sillero J.C., Moral A., Cubero J.I., Rubiales D. 2004. Effect of sowing date and host resistance on the establishment and development of Orobanche crenata in faba bean and common vetch. Weed Res., 44:282-288.

Pérez-de-Luque A., Jorrìn J., Cubero J.I., Rubiales D. 2005a. Resistance and avoidance against Orobanche crenata in pea (Pisum spp.) operate at different developmental stages of the parasite. Weed Res., 45:379-387.

Pérez-de-Luque A., Rubiales D., Cubero J.I., Press M.C., Scholes J., Yoneyama K., Takeuchi Y., Plakhine D., Joel D.M. 2005b. Interaction between Orobanche crenata and its host legumes: unsuccessful haustorial penetration and necrosis of the developing parasite. Ann. Bot., 95:935-942.

Pérez-de-Luque A., Gonzàlez-Verdejo C.I., Lozano M.D., Dita M.A., Cubero J.I., Gonzàlez-Melendi P., Risueno M.C., Rubiales D. 2006a. Protein cross-linking, peroxidase and $\mathrm{B}-1,3$-endoglucanase involved in resistance of pea against Orobanche crenata. J. Exp. Bot., 57:1461-1469.

Pérez-de-Luque A., Lozano M.D., Cubero J.I., GonzàlezMelendi P., Risueno M.C., Rubiales D. 2006b. Mucilage production during the incompatibile interaction between Orobanche crenata and Vicia sativa. J. Exp. Bot., 57:931-942.

Pérez-de-Luque A., Lozano M.D., Rubiales D. 2006c. Resistencia post-haustorial a Orobanche crenata en garbanzo. In: de los Mozos Pascual M., Giménez Alvear M.J., Rodrìguez Conde M.F., Sànchez Vioque R. (eds.): Nuevos retos y oportunidades de las leguminosas en el sector agroalimentario espanol, 361-368. Consejerìa de Agricoltura de Castilla-La Mancha, Toledo, Spain.

Pérez-de-Luque A., Lozano M.D., Moreno M.T., Testillano P.S., Rubiales D. 2007. Resistance to broomrape (Orobanche crenata) in faba bean (Vicia faba): cell wall changes associated with pre-haustorial defensive mechanisms. Ann. Appl. Biol., 151:89-98.

Pérez-de-Luque A., Moreno M.T., Rubiales D. 2008. Host plant resistance against broomrapes (Orobanche spp.): defence reactions and mechanisms of resistance. Ann. Appl. Biol., 152:131-141. 
Petzoldt K. 1979. Bacterial nodules of Rhizobium leguminosarum and Orobanche crenata germination and penetration of broad beans with an integrated control program. In: Musselmann L.J., Worsham A.D., Eplee R.E. (eds.): Proc. $2^{\text {nd }}$ International Symposium on Parasitic Weeds. Raleigh, USA: North Carolina State University, 260-268.

Pieterse A.H., Aalders A.J.G. 1986. The effect of Vicia faba sowing density on broomrape attack. FAO Plant Prot. Bull., 34:209-211.

Pieterse A.H. 1991. The effect of nitrogen fertilizers on the germination of seed of Striga hermonthica and Orobanche crenata. In: Wegmann K., Musselmann L.J. (eds.): Progress in Orobanche Research, Proceeding of the International Workshop on Orobanche Research, 19-22 August 1989, Obermarchtal FRG, 115-124.

Pieterse A.H., García-Torres L., Al-Menoufi O.A., Linke K.H., Borg S.J. 1992. Integrated control of the parasitic angiosperm Orobanche (broomrape). In: Proceedings of the $2^{\text {nd }}$ International Food Legume Research Conference, 12-16 April 1992, Cairo, Egypt.

Portnoy V.H., Katzir N., Joel D.M. 1997. Species identification of soil-borne Orobanche seeds by DNA fingerprinting. Pestic. Biochem. Physiol., 58:49-54.

Press M.C., Graves J.D., Stewart G.R. 1990. Physiology of the interaction of angiosperm parasites and their higher plant hosts. Plant, Cell Environ., 13:91-104.

Rajanna L., Shivamurthy G.R., Niranjana R., Vijay C.R. 2005. Occurrence of phloem in the haustorium of Aeginetia pedunculata Wall. - a root holoparasite of Orobanchaceae. Taiwania, 50, 2:109-116. (Confirmaing the occurrence of phloem and callose deposition on sieve plates in the haustorium of A. pedunculata).

Restuccia G., Mauromicale G. 1991. Influenza degli estratti radicali di alcune leguminose da granella sulla germinazione del seme di Orobanche crenata Forsk. Rivista di Agronomia, 25:422-426.

Restuccia G., Mauromicale G., Marchese M., Restuccia A., Sapienza O. 2001. Solarizzazione e controllo di Orobanche crenata Forsk. in Vicia faba L. Atti del XXXIV Convegno dalla Società Italiana di Agronomia, 17-21 settembre 2001, Pisa, Italy, 226-227.

Restuccia G., Mauromicale G., Maugeri G., Restuccia A., Marchese M., Longo A.M.G. 2005. Effetti della solarizzazione sulla fava da granella coltivata in ambiente mediterraneo. Tecnica Agricola, 1-2:3-14.

Restuccia A., Lo Monaco A., Longo A.M.G., Mauromicale G., Restuccia G. 2007. Influenza della solarizzazione del terreno e della concimazione organica sulla seed bank e sulla vitalità dei semi di Orobanche spp. Atti del XXXVII Convegno Nazionale della Società Italiana di Agronomia, 13-14 settembre 2007, Italy, 301-302.

Román B., Torres A.M., Rubiales D., Cubero J.I., Satovic Z. 2002. Mapping of quantitative trait loci controlling broomrape (Orobanche crenata Forsk.) resistance in faba bean (Vicia faba L.). Genome, 45:1057-1063.

Rubiales D., Perez-De-Luque A., Cubero J.I., Sillero J.C. 2003a. Crenate broomrape (Orobanche crenata) infection in field pea cultivars. Crop Prot., 22:865-872.

Rubiales D., Alcantara C., Sillero J.C. 2004. Variation in resistance to crenate broomrape (Orobanche crenata) in species of Cicer. Weed Res., 44:27-32.

Rubiales D., Moreno M., Sillero J. 2005. Search for resistance to crenate broomrape (Orobanche crenata Forsk.) in pea germplasm. Genet. Resour. Crop Evol., 52:853-861.

Saghir A.R., Foy C.L., Hameed K.M., Drake C.R., Tolin S.A. 1973. Studies on the biology and control of Orobanche ramosa L. In: Proceedings Eur. Weed Reserch Counc. Symposium on Parasitic Weeds. Malta, 106-116.

Salisbury F.B., Ross C.W. 1996. Plant Physiology $4^{\text {th }}$ edn. Wadsworth Publishing Company, Belmont, CA.

Sauerborn J., Masri H., Saxena M.C., Erskine W. 1987. A rapid test to screen lentil under laboratory conditions for susceptibility to Orobanche. LENS, 14:15-16.

Sauerborn J., Linke K.H., Saxena M.C., Koch W. 1989. Solarization: a physical control method for weeds and parasitic plants (Orobanche spp.) in Mediterranean agriculture. Weed Res., 29:391-397.

Sauerborn J. 1991a. The economic importance of the phytoparasites Orobanche and Striga. In: Ransom J.K., Musselmann L.J., Worsham A.D., Parker C. (eds.): Proceedings of the $5^{\text {th }}$ International Symposium on Parasitic Weeds, Nairobi, Kenya, 137-143.

Sauerborn J. 1991b. Parasitic flowering plants in agricultural ecosystems of West-Asia. Flora et Vegetatio Mundi IX, 83-93.

Sauerborn J. 1993. Natural antagonists for parasitic weed control in agroecosystems. In: Proceedings of the International Symposium Indian Society of Weed Science, Hisar, India, I:29-33.

Sauerborn J., Kroschel J. 1996. Biologische Unkrautbekämpfung. In: Sauerborn J. (ed.): Pflanzengesundheit in Agrarökosystemen der Tropen. Giessener Beiträge zur Entwicklungsforschung, Bd., 23:123-138.

Sauerborn J., Müller-Stöver D., Hershenhorn J. 2007. The role of biological control in managing parasitic weeds. Crop Prot., 26:246-254.

Schmitt U., Schluter K., Boarsma P.A. 1979. Chemical control of Orobanche crenata in broadbean. FAO Plant Prot. Bull., 27:89-91.

Schnell H., Linke K.H., Sauerborn J. 1994. Trap cropping and its effects on yield and Orobanche crenata Forsk. infestation on following pea (Pisum sativum L.) crops. Tropical Science, 34:306-314.

Serghini K., Pérez-De-Luque A., Castejòn-Munoz M., Garcìa-Torres L., Jorrìn J.V. 2001. Sunflower (Helianthus annuus L.) response to broomrape (Orobanche cernua Loefl.) parasitism: induced synthesis and excretion of 7-hydroxylated simple coumarins. J. Exp. Bot., 52:2227-2234.

Sillero J.C., Moreno M.T., Rubiales D. 2005. Sources of resistance to crenate broomrape among species of Vicia. Plant Dis., 89:23-27. 
Song W.J., Zhou W.J., Jin Z.L., Cao D.D., Joel D.M., Takeuchi Y., Yoneyama K. 2005. Germination response of Orobanche seeds subjected to conditioning temperature, water potential and growth regulator treatments. Weed Res., 45:467-476.

Steinkellner S., Lendzemo V., Langer I., Schweiger P., Khaosaad T., Toussaint J.P., Vierheilig H. 2007. Flavonoids and strigolactones in root exudates as signals in symbiotic and pathogenic plant-fungus interactions. Molecules, 12:1290-1306.

Stewart G.R., Nour J., Macqueen M., Shah N. 1984. Aspects of the biochemistry of Striga. In: Proceedings of the international workshop on Striga biology and control. ICSU, 161-178.

Surov T., Aviv D., Aly R., Joel D.M., Goldman-Guez T., Gressel J. 1997. Generation of transgenic asulam-resistant potatoes to facilitate eradication of parasitic broomrapes (Orobanche spp.), with the sul gene as the selectable marker. Theor. Appl. Genet., 96:132-137.

Ter Borg S.J., Willemsen A., Khalil S.A., Saber H.A., Verkleij J.A.C., Pieterse A.H. 1994. Field study of the interaction between Orobanche crenata Forsk. and some lines of Vicia faba L. in Egypt. Crop Prot., 13:611-616.

Ter Borg S.J. 1999. Broomrape resistance in faba bean: what do we know? In: Cubero J.I., Moreno M.T., Rubiales D., J. Sillero J. (eds.): Resistance to broomrape, the state of the art. DGIFA, Junta de Andalucìa, Sevilla, Spain, 25-41.

Tutin T.G., Heywood V.H., Burges N.A., Moore D.M., Valentine D.H. 1981. Flora Europea. Cambridge University Press, 3, 290.

Verkleij J.A.C., Jansen J., Pieterse A.H. 1986. A preliminary study on isoenzyme variation in Orobanche crenata and Orobanche aegyptiaca from Sirya. In: Ter Borg S.J. (ed.): Proceedings of a Workshop on the Biology and Control of Orobanche, LH/VPO, Wageningen, The Netherlands, 154-159.

Van Hezewijk M.J., Verkleijm J.A.C., Pieterse A.H. 1991. Temperature dependence of germination in Orobanche crenata. In: Wegmann K., Musselmann L.J. (eds.): Progress in Orobanche Research. Proceeding of the International Workshop on Orobanche Research, 19-22 August 1989, Obermarchtal FRG, 125133.
Van Hezewijk M.J., Van Beem A.P., Verkleij J.A.C., Pieterse A.H. 1993. Germination of Orobanche crenata seeds as influenced by conditioning temperature and period. Can. J. Bot., 71:786-792.

Van Hezewijk M.J., Linke K.H., Lòpez-Granados F., AlMenoufi O.A., García-Torres L., Saxena M.C., Verkleij J.A.C., Pieterse A.H. 1994. Seasonal changes in germination response of buried seeds of Orobanche crenata. Weed Res., 34:369-376.

Visser J.H., Dörr I. 1987. The haustorium. In: Musseknan L.J. (ed.): Parasitic weeds in agriculture, vol. I. Striga, 91-106. CRC Press, Boca Raton, USA.

Weldeghiorghis E.K. 1998. Germination Biology of Orobanche Species and Implications for Integrated Control. PhD Thesis. Reading University, UK. (Incluing detailed modelling of the rates of germination, induction of secondary dormancy and loss of viability in seeds of $O$. aegyptiaca, O. crenata and $O$. minor under different moisture and temperature regimes).

Whitney P.J. 1972. The translocation of herbicide from bean (Vicia faba) to broomrape (Orobanche crenata). Ann. Appl. Biol., 72:205-10.

Wigchert S.C.M., Zwanenburg B. 1999. A critical account on the inception of Striga seed germination. Journal of Agricultural and Food Chemistry, 47:1320-1325.

Zahran M.K. 1970. Satisfactory control of Orobanche crenata in broadbeans by soil fumigation in the UAR. Proc. Br. Weed Control Conf., 10:680-684.

Zaitoun F.M.F., Al-Menoufi O.A., Weber H.C. 1991. Loss assessment and forecasting work on plant diseases: 1 . A new method for assessment of loss in Vicia faba through infection by Orobanche crenata. In: Wegmann K., Musselmann L.J. (eds.): Progress in Orobanche Research. Proceeding of the International Workshop on Orobanche Research, 19-22 August 1989, Obermarchtal FRG, 167-184.

Zermane N., Kroschel J., Souissi T. 2004. Options for biological control of the parasitic weed Orobanche in North Africa. In: Peters K.J., Kirschke D., Manig W. et al. (eds.): Book of Abstracts 2004. Rural Poverty Reduction through Research for Development and Transformation: International Research on Food Security, Natural Resource Management and rural Development, Humboldt University, Berlin, Germany. 